\title{
Influence of land configuration and fertilization techniques on soybean (Glycine max (L.) Merrill.) productivity, soil moisture and fertility
}

\author{
Abhijit Kishanrao KADAM ${ }^{1}$, Agbesi Kwadzo KETEKU ${ }^{1,2,3}$, Suchada DANA ${ }^{4}$, Precious Kwaku BLEGE ${ }^{5}$ \\ Received July 11, 2019 accepted January 2, 2020. \\ Delo je prispelo 11. julija 2019, sprejeto 2. januarja 2020.
}

\begin{abstract}
Influence of land configuration and fertilization techniques on soybean (Glycine max (L.) Merrill.) productivity, soil moisture and fertility

Abstract: An experiment was conducted to investigate the impact of flatbed (FB), ridges and furrows (RF) and broad bed furrows (BBF) combined with recommended fertilizer dose $\mathrm{N}_{30} \mathrm{P}_{60} \mathrm{~K}_{30} \mathrm{~kg} \mathrm{ha}^{-1}\left(\mathrm{~F}_{1}\right), 75 \% \operatorname{NPK}\left(\mathrm{F}_{2}\right), 125 \% \operatorname{NPK}\left(\mathrm{F}_{3}\right)$, $75 \% \mathrm{NPK}+25 \% \mathrm{~N}$ through farm yard manure (FYM) $-\mathrm{F}_{4}$, $75 \% \mathrm{NPK}+2$ sprays of micro nutrient mixture (Fe, $\mathrm{Zn}, \mathrm{Cu}$, $\mathrm{Mn}, \mathrm{B}$ and Mo) $-0.5 \%$ at 35 and 60 days after sowing (DAS)$\mathrm{F}_{5}$ and $75 \% \mathrm{NPK}+2$ sprays of $\mathrm{KNO}_{3}-0.5 \%$ at 35 and $1.0 \%$ at 60 DAS $\left(\mathrm{F}_{6}\right)$ on the productivity of soybean in a split plot design. BBF stored $14.15 \%$ more soil water and produced $1058.97 \mathrm{~kg} \mathrm{ha}^{-1}$ more yield than FB. A significant $3.76 \mathrm{~kg} \mathrm{ha}^{-1}$ $\mathrm{mm}$ rain water use efficiency was notice in BBF compared to FB. The yield increment recorded under $\mathrm{F}_{6}$ was $15.6 \%$ higher than $\mathrm{F}_{1}$. Grain nitrogen and oil contents were highest in $\mathrm{F}_{3}$. The residual soil fertility was much improve by $\mathrm{F}_{3}$ and $\mathrm{F}_{5}$. Our result demonstrated that the combination of $\mathrm{BBF}$ and $\mathrm{F}_{6}$ were the best technique to increase soybean yield in the Vertisol soil.
\end{abstract}

Key words: foliar fertilization; land configuration; soil moisture; soybean nutrition; yield
Vpliv priprave zemljišča in gnojilnih tehnik na pridelek soje (Glycine max (L.) Merrill.), na vlažnost in rodovitnost tal

Izvleček: Poskus z deljenkami je bil narejen za preučitev načinov priprave zemljišča kot so ravno zemljišče (FB), grebeni in brazde $(\mathrm{RF})$ in široki grebeni $(\mathrm{BBF}) \mathrm{v}$ kombinaciji $\mathrm{s}$ priporočenimi odmerki gnojenja: $\mathrm{N}_{30} \mathrm{P}_{60} \mathrm{~K}_{30} \mathrm{~kg} \mathrm{ha}^{-1}\left(\mathrm{~F}_{1}\right), 75 \%$ NPK $\left(\mathrm{F}_{2}\right), 125 \% \mathrm{NPK}\left(\mathrm{F}_{3}\right), 75 \% \mathrm{NPK}+25 \% \mathrm{~N}$ kot hlevski gnoj (FYM) $\left(\mathrm{F}_{4}, 75 \% \mathrm{NPK}+2\right.$ kratno pršenje $\mathrm{z}$ mešanico mikrohranil (Fe, Zn, Cu, Mn, B in Mo), 0,5 \% 35 in 60 dni po setvi $(\mathrm{DAS})\left(\mathrm{F}_{5}\right)$ in $75 \% \mathrm{NPK}+2$ pršenja $\mathrm{s} \mathrm{KNO}_{3}-0,5 \% 35$ in $1,0 \% 60$ dni po setvi DAS $\left(\mathrm{F}_{6}\right)$ na pridelek soje. Pri BBF se je ohranilo $14,15 \%$ več talne vode in dalo za $1058,97 \mathrm{~kg} \mathrm{ha}^{-1}$ več pridelka kot FB. Pri BBF je bila ugotovljena tudi značilno večja učinkovitost $\left(3,76 \mathrm{~kg} \mathrm{ha}^{-1}-\mathrm{mm}\right)$ izrabe deževnice kot pri FB. Povečanje pridelka je bilo pri $\mathrm{F}_{6}$ za $15,6 \%$ večje kot pri $\mathrm{F}_{1}$.Vsebnost dušika in olja $\mathrm{v}$ zrnih sta bili največji pri $\mathrm{F}_{3}$. Rodovitnost tal se je znatno povečala pri $\mathrm{F}_{3}$ in $\mathrm{F}_{5}$. Rezultati so pokazali, da je bila kombinacija $\mathrm{BBF}$ in $\mathrm{F}_{6}$ najboljša tehnika za povečanje pridelka soje $\mathrm{v}$ tleh na vertisolu.

Ključne besede: foliarno gnojenje; oblikovanost zemljišča; vlažnost tal; gnojenje soje; pridelek

\footnotetext{
1 Vasantrao Naik Marathwada Agric. University, Dept. of Agronomy and AICRP on Dryland Agriculture, India

2 Naresuan University, Faculty of Agriculture, Natural Resource and Environment, Thailand

3 Corresponding author, e-mail: keteku.agbesi@yahoo.com

4 Udon Thani Rice Research Center, Nikhom Song Khro, Thailand

5 University for Development Studies, Faculty of Agriculture, Dept. of Agricultural Mechanization and Irrigation Technology, Ghana

This paper is a part of the MS.c thesis of A.K.K. under supervision of A.K.K.
} 


\section{INTRODUCTION}

Soybean (Glycine max (L.) Merrill.) is the most important oil seed crop in India, owing to its several domestic and industrial uses, besides its use in numerous food preparations and animal feed formulations. Soybean accounts for about $53 \%$ of the world production share among the oilseed crops, and has therefore, occupied an important place in most farming systems in the Marathwada region of Maharashtra State, India (Talukdar \& Shivakumar, 2016). However, under rain fed systems, soil moisture stress of 15-21 days at any growth phase of the soybean crop results in a significant yield loss in the Maharashtra State (Patil, 1992). These yield losses are especially severe in the early determinate genotypes (Chaturvedi et al., 2012). The drying and cracking nature of the vertisol soils in the region, coupled with their low fertility aggravates the situation (Keteku et al., 2016). To effectively manage the problem amidst irrigation difficulties, technologies targeted at soil moisture and nutrient conservation such as land layout are very crucial. Thus soil, water and nutrient conservation technologies are the key adaptation strategies to mitigate the rapid loss of moisture (Kurukulasuriya \& Rosenthal, 2003); and help plants withstand the occurrence of short dry spells under rain fed farming. An earlier studies on soil management strategies, aimed to increase crop productivity revealed that, modification of land such as broad bed furrow, and ridges and furrows in vertisol soils were superior to flatbed under watershed development (Raut \& Taware, 1997). It is noteworthy to also mention that, soybean is a high protein and energy crop, as such it has a high nutrient requirement. Unfortunately, the inadequate and imbalance fertilization practiced by farmers, also adds to the problem of decreasing yield (Chaturvedi et al., 2012).

Usually, the farmer's fertilizer programs focus solely on soil applied NPK, without plans for foliar application, however recent studies had shown the foliar fertilization enhance soybean yield (Gowthami \& Rama, 2014; Chaturvedi et al., 2012). Others had also reported that micronutrients are essential for the optimum utilization of major nutrients, and also for the production of organic compounds (Gowthami \& Rama, 2014; Intanon, 2013). Numerous previous studies had equally reported the impact of combine major and micro nu- trients on crop yield (Keteku et al., 2018; Intanon, 2013; Salem \& El-Gizawy 2012). Soybean is a focus crop for the realization of the Sustainable Development Goals (Shinde et al., 2009). Climate change threatens rainfall pattern and therefore, the achievement of the Sustainable Development Goals aimed at poverty and hunger reduction. Therefore our work is designed to investigate (i) the influence of land modification on soil moisture and soybean yield, and (ii) the effect of different fertilization techniques on soybean yield and soil properties. This is necessary to find the appropriate land configuration and techno-economic nutrient package for soybean production under such vertisol soil.

\section{MATERIALS AND METHODS}

\subsection{EXPERIMENTAL SITE}

The experiment was conducted at the experimental farms of the All India Coordinated Research Project on Dryland Agriculture (AICRP) station at Vasantrao Naik Marathwada Agriculture University (VNMKV), Marathwada, India, during rainy season, 2017. VNMKV is situated on a latitude and longitude of $19^{\circ} 15^{\prime} 28.0440^{\prime \prime} \mathrm{N}$ and $76^{\circ} 46^{\prime} 25.4748^{\prime \prime}$ E respectively, and at $409 \mathrm{~m}$ above mean sea level. The average annual precipitation of the region is $963 \mathrm{~mm}$, distributed in 48 rainy days, mostly during June - October. The mean maximum and minimum temperatures are $32.2{ }^{\circ} \mathrm{C}$ and $19.0^{\circ} \mathrm{C}$ respectively. The total rainfall received during the trail was $308.4 \mathrm{~mm}$, distributed in 35 rainy days. A total effective rainfall of $281.7 \mathrm{~mm}$ was recorded. Relative humidity was in the ranges of $81.8 \%$ - $48.1 \%$, while that of mean bright sunshine was $6.7 \mathrm{hr}$. The mean evapotranspiration was $5.4 \mathrm{~mm}$ as well. The research soil was vertisol in classification (WRB), medium deep black, well drained, low in fertility, except $\mathrm{K}$ and levelled in topography. The soil nutrients and moisture contents at a depth of $(0-20 \mathrm{~cm})$ before the trial are shown in (Table 1). The $\mathrm{pH}$ of the soil was alkaline.

\subsection{EXPERIMENTAL PLAN}

The experiment was 2 factorial, conducted in split plot design with 3 replications. The treatments were

Table 1: Soil properties before the trial (sample size $(\mathrm{n})=3$ )

\begin{tabular}{|c|c|c|c|c|c|c|c|c|c|}
\hline $\mathrm{N}$ & $\mathrm{P}$ & $\mathrm{K}$ & $\mathrm{Fe}$ & $\mathrm{Zn}$ & $\mathrm{Cu}$ & $\mathrm{Mn}$ & B & \multirow[t]{2}{*}{$\mathrm{pH}(1: 1.5)$} & \multirow[t]{2}{*}{ Moisture \% } \\
\hline \multicolumn{3}{|c|}{$\%$} & \multicolumn{5}{|c|}{$\mathrm{mg} / \mathrm{kg}$} & & \\
\hline 0.514 & 0.313 & 1.27 & 5.24 & 1.33 & 0.32 & 2.24 & 0.37 & 7.9 & 17.85 \\
\hline
\end{tabular}


composed from 3 land configurations as main plots treatments and 6 fertilization strategies as subplots treatments, making a total of 18 treatment combinations. The 3 land configurations were; flatbed (FB), ridges \& furrow (RF) and broad bed furrow (BBF), while the 6 fertilizers were a combination of urea, single super phosphate and murate of potash; recommended fertilizer dose $\mathrm{N}_{30} \mathrm{P}_{60} \mathrm{~K}_{30} \mathrm{~kg} \mathrm{ha}^{-1} \mathrm{~F}_{1}=100 \%$ by mass, $75 \%$ $\operatorname{NPK}\left(\mathrm{F}_{2}\right), 125 \% \mathrm{NPK}\left(\mathrm{F}_{3}\right), 75 \% \mathrm{NPK}+25 \% \mathrm{~N}$ through 5 tons FYM ha ${ }^{-1}\left(\mathrm{~F}_{4}\right), 75 \% \mathrm{NPK}+2$ sprays of $0.5 \%$ micro nutrient mixture (Fe, $\mathrm{Zn}, \mathrm{Cu}, \mathrm{Mn}, \mathrm{B}$ and $\mathrm{Mo})-50$ $\mathrm{ml}$ per $10 \mathrm{~L}$ water at 35 and $60 \mathrm{DAS}\left(\mathrm{F}_{5}\right)$ and $75 \% \mathrm{NPK}$ +2 sprays of $0.5 \% \mathrm{KNO}_{3}-50 \mathrm{ml}$ per $10 \mathrm{~L}$ water at 35 and $1.0 \%-100 \mathrm{ml}$ per $10 \mathrm{~L}$ water at 60 DAS $\left(\mathrm{F}_{6}\right)$. Thus, $2500 \mathrm{ml}$ for $0.5 \%$ and $5000 \mathrm{ml}$ for $1 \%$ to $500 \mathrm{~L}$ water was used for ha. The $\mathrm{KNO}_{3}$ contained $13 \%$ and $45 \%$ nitrogen and potassium, respectively. The gross and net plot sizes used were $5.4 \times 6.0 \mathrm{~m}$ and $4.5 \times 5.0 \mathrm{~m}$, in length and width respectively.

The land was ploughed with a tractor drawn plough to a depth of $20 \mathrm{~cm}$ and harrowed twice before the preparation of the ridges and furrows, and broad bed furrows. The ridges measured $45 \mathrm{~cm}$ wide and $15 \mathrm{~cm}$ high while that of the broad bed furrows were $120 \mathrm{~cm} \times 30 \mathrm{~cm} \times 15 \mathrm{~cm}$ in width, length and height, respectively. The seeds of determinant soybean variety ('MAUS-162') were treated with Rhizobium culture (Bradyrhizobium japonicum (Kirchner 1896) Jordan 1982) and phosphate solubilizing bacteria (PSB), and sown at the recommended spacing of $45 \times 5 \mathrm{~cm}^{2}$. But on the broad bed furrows a planting distance of $37.5 \times$ $5 \mathrm{~cm}^{2}$ was used so as to obtain uniform plant population in all plots. A rate of $65 \mathrm{~kg} \mathrm{ha}^{-1}$ was used, two seeds were dibbled per hill and thinned out after 14 DAS to maintain one seedling per hill. The solid fertilizers were applied by side placement method, $30 \%$ was applied at sowing and the remaining $70 \%$ applied at 30 DAS. The FYM was broadcasted and raked into the soil on the flatbed and broad bed furrows, but in the ridges and furrows, it was applied uniformly in the lines opened for sowing. The 'MAUS-162' seeds were sourced from the seed processing plant, VNMKV while the fertilizers, Rhizobium culture and PSB were obtained from AICRP, VNMKV. One spraying of Chloropyriphos 20 EC was performed to control leaf eating caterpillar. Two hand weeding and one hoeing were performed to control weeds and also loosen the soil for good aeration.

\subsection{DATA COLLECTION}

Before the trial, soil cores were collected from 12 spots on the research site at a depth of $(0-20 \mathrm{~cm})$ with the hand auger for the assessment of soil fertility and $\mathrm{pH}$. The routine methods of $\mathrm{Lu}$ (1999) were followed for the determination of soil nutrients. Total nitrogen, phosphorus and potassium were determine by the Kjeldahl method, Bray's no. II method and Neutral $\mathrm{N}$ ammonium method, respectively. The wet digestion (nitric-perchloric digestion) method was adopted for the analysis of iron, zinc, copper, manganese and boron. Soil $\mathrm{pH}$ was measured at 1:1.5 solution ratio, using the electrode (H19017 Microprocessor) pH meter. Another soil cores were also taken from a depth of $(0-15 \mathrm{~cm}$ and $15-30 \mathrm{~cm}$ ) for the determination of soil moisture content. Using the gravimetric method, the percentage soil moisture content were calculated for each depth and the mean worked out using the formula in (Equation 1). $50 \mathrm{~g}$ of the sample soil was oven dried at $105^{\circ} \mathrm{C} \pm$ $5{ }^{\circ} \mathrm{C}$ for $12 \mathrm{~h}$.

Moisture $\%=\left(m_{2}-m_{1}\right) /\left(m_{2}\right) \times 100$

Where; $m_{1}=$ mass of wet soil sample, $m_{2}=$ mass of oven dried soil sample

Fifteen representative sampled plants were randomly selected in each plot and tagged for the measurement of vegetative growth. Plant height, number of leaves, number of branches, leaf area and total dry matter mass per plant were measured after 30 DAS at 15 days interval. At each periodic data collection, two representative plant were uprooted, processed and oven dried at $72{ }^{\circ} \mathrm{C} \pm 2{ }^{\circ} \mathrm{C}$ for $12 \mathrm{~h}$ for total dry matter measurement. However on the harvest day, total dry matter weight was again measured from the 15 sampled plants in each plot. Leaf area was measured from the sampled plants uprooted for dry matter studies. The leaves were aerated into leaflets and grouped into three class viz., small, medium and big. The maximum length and diameter of five leaflets from each group were measured using the hand held laser leaf area meter (CID Bio-Science, Inc.), and the method of Pawar (1978) was used to calculate the leaf area/plant (Equation 2).

$$
\text { Leaf area/plant }\left(\mathrm{dm}^{2}\right)=\sum_{i=0}^{n=3}(L \times D) K(\text { Eqn 2) }
$$

Where; L, D, $\mathrm{n}$ and $\mathrm{K}$ are leaf length, leaf diameter, number of leaves and leaf area constant for soybean (0.689), respectively. Only the final values were reported here. Also, yield components namely; number of pod plant $^{-1}$, pod mass plant ${ }^{-1}$, grain mass plant ${ }^{-1}$ and 1000 seeds mass were measured from the fifteen sampled plants. After harvesting (120 DAS), grain mass plot $^{-1}$ and straw mass plot $^{-1}$ were measured, all the plants in the net plots were consider. The values were later converted to grain yield ha ${ }^{-1}$. The biological yield produce 
was determined as the summation of grain mass plot $^{-1}$ and straw mass plot $^{-1}$ and again converted into ha. Harvest index (HI) was calculated as indicated in (Equation $3)$. (Eqn 3)

$\mathrm{HI} \%=($ Biological yield $(\mathrm{kg})) /($ Grain yield $(\mathrm{kg})) \times 100$

The protein and oil content of the seeds were determined for quality assessment, grain nitrogen content was estimated by the micro Kjeldahal method (A.O.A.C., 1975), and was converted into crude protein percentage by multiplying the percent nitrogen with 6.25. Soxhlet ether extraction method was used to estimate the oil content.

After the trial, soil samples were again sampled and the properties estimated by the same methods above. Rain water use efficiency (RWUE) was computed by the formula (Equation 4) and expressed in $\mathrm{kg} / \mathrm{ha}-\mathrm{mm}$.

RWUE $\left(\mathrm{kg} \mathrm{ha}^{-1}-\mathrm{mm}\right)=\left(\right.$ Yield $\left.\mathrm{kg} \mathrm{ha}^{-1}\right) /($ Moisture use(effective rainfall) $\mathrm{mm}$ )

(Eqn 4)

\subsection{STATISTICAL ANALYSIS}

The data recorded were subjected to Analysis of Variance (ANOVA) using SPSS 21 statistical package. The variation between treatments means were quantified at a probability of $5 \%$. Duncan's Multiple Range Test (DMRT) analysis was performed and presented in tables, in alphabets with 'a' depicting highest value. Interactions between factors were not significant, hence not presented. Regression analysis was used to show the relationship between some variables.

\section{RESULTS AND DISCUSSION}

\subsection{INFLUENCE OF LAND CONFIGURATION ON SOIL MOISTURE CONTENT}

The impact of land configuration on soil moisture content $(0-30 \mathrm{~cm})$ was significant $(p<0.05)$ as shown in Figure 1. Soil moisture content increased gradually from 30 to $90 \mathrm{DAS}$ in the $\mathrm{BBF}$ and RF, compared to FB which recorded a decrease at 90 DAS. At 30, 60, 75 and 90 DAS, BBF conserved the highest significant soil moisture of 19.86, 27.30, 23.55 and $20.43 \%$, respectively when compared to RF and FB. Similarly, RF stored a significant amount of moisture on 60 and 90 DAS (27.29\% and $18.30 \%$, respectively) than FB. The furrows between the BBF and RF prevented the runoff of rain water and enhanced the infiltration of water into the soil. Probably the size of BBF also enhanced water conservation, as it has less surface area for evapora- tion when compare to the RF. In-situ land management strategies that reduces water lost caused by runoff and evaporation, and improves water infiltration and storage would lead to increase the amount of water retained in the soil for crops (Singh et al., 2014). BBF conserved $14.15 \%$ more water than FB. Our results agrees with the previous findings of Shinde et al. (2009), Bharambe et al.(1999) and Patil et al.(1992) that BBF and RF conserved more water than FB. According to Kumar et al. (2010), furrow irrigated bed planting systems, on an average retained $40 \%$ more water, compared to $\mathrm{FB}$ planting systems. Consistently, Selvarajua et al. (1999) also reported $17 \%$ more soil moisture in BBF compare to FB. In contrasts to our findings, Singh et al. (2018) reported $28.54 \%$ soil moisture in RF and $27.58 \%$ in $\mathrm{BBF}$, nevertheless they similarly reported the least soil moisture in FB. The principal aim of land configuration are; the preparation of a conducive seedbed for seed germination and seedling growth, conservation of soil moisture that influences the infiltration characteristics of the soil, and also, provides adequate soil depth for optimum root growth and proper fertilizers placement. The land configuration that stores enough moisture will reduce soil moisture tension, while improving nutrient flow and their availability for crop uptake (Singh \& Kumar, 2009). Our findings has demonstrated that BBF and RF can conserve more moisture than FB.

\subsection{INFLUENCE OF TREATMENTS ON SOYBEAN GROWTH}

The results in Table 2 showed that soybean growth variables were significantly $(p<0.05)$ influenced by the various land configurations and fertilizers strategies. Interaction between factors were not significant and were therefore not discussed. Soybean height and number of branches $(55.98 \mathrm{~cm}$ and 4.95$)$ respectively, were superior in BBF compared to RF and FB. However, leaf area plant $^{-1}$ was equal between $\mathrm{BBF}$ and RF, while that of total dry matter produced did not significantly differ among the land layouts. But the greatest dry matter mass of $24.20 \mathrm{~g}$ was produced by BBF. The high growth observed in BBF and RF could be related to the availability of optimum soil moisture at the key vegetative phase of the crop. When soil moisture tension is low, the ability of crops to absorb nutrients and that of the soil to supply nutrients are optimal, and so, nutrients availability are improved (Singh \& Kumar 2009). In addition, the BBF and RF could also provide adequate aeration and a good soil depth for root expansion and nutrient exploration (Singh et al., 2014). From our re- 


\section{Flat Bed $\quad$ Ridges \& Furrow Bed $\quad$ Broad Bed Furrows}

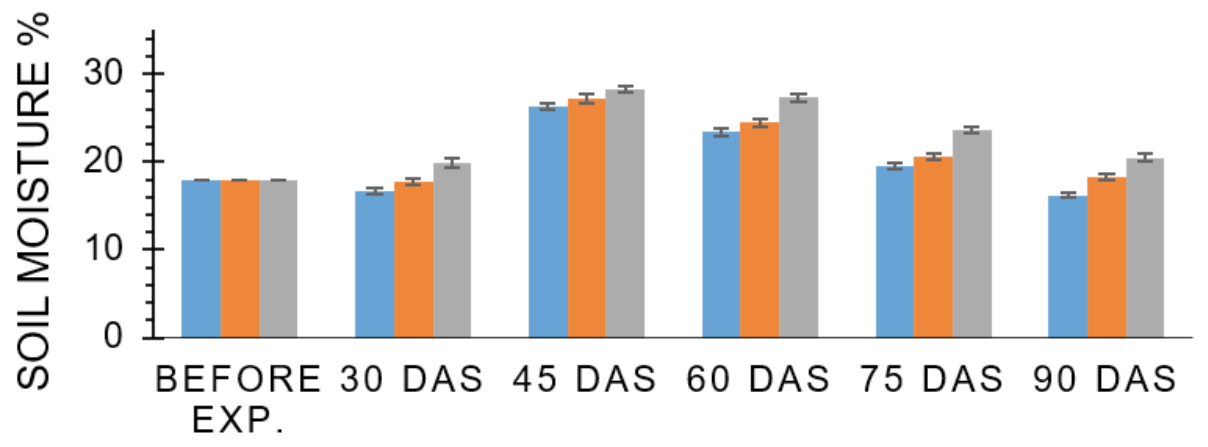

\section{DAYS AFTER SOWING}

Figure 1: Effect of land configuration on soil moisture content $(0-30 \mathrm{~cm})$ during the trial

sults, it is evident that land layout had significant effect on growth.

Also, the application of $\mathrm{F}_{6}(75 \% \mathrm{NPK}+2$ sprays of $\mathrm{KNO}_{3}-0.5 \%$ at $35 \mathrm{DAS}$ and $1.0 \%$ at $\left.60 \mathrm{DAS}\right)$ recorded the highest soybean height plant ${ }^{-1}$, number of branches plant ${ }^{-1}$, leaf area plant ${ }^{-1}$ and total dry matter mass plant ${ }^{-1}$ of $53.12 \mathrm{~cm}, 5.17,22.10 \mathrm{dm}^{2}$ and $25.80 \mathrm{~g}$ respectively, but it was not significant when compared to $\mathrm{F}_{3}$ and $\mathrm{F}_{5}$ (dry matter). Increasing the NPK rate from F1 to F3 also increased soybean growth variables but did not give significant results. According to our result, $\mathrm{F}_{1}, \mathrm{~F}_{2}$ and $\mathrm{F}_{4}$ treatments had a similar effect on soybean growth. The performance of $\mathrm{F}_{6}$ might probably be due to the rapid and efficient nutrients absorption resulting from the foliar spray of $\mathrm{KNO}_{3}$ which contained $13 \%$ $\mathrm{N}$ and $46 \% \mathrm{~K}$, while that of $\mathrm{F}_{3}$ can be attributed to its higher NPK nutrients. Nitrogen particularly, is a principal constituent of protein, chlorophyll and the hormones which are essential for cell expansion and an increase in the vegetative apparatus of crops (Keteku et al., 2016; Nsoanya \& Nweke, 2013). Besides having nitrogen which is an integral component of cell division in the fertilizers, the micronutrients do also influence cell division, chlorophyll construction and photosynthesis (Intanon 2013). This may probably explains why $\mathrm{F}_{5}$ produced a similarly high total dry matter mass of $24.83 \mathrm{~g}$, despite its low NPK content when compared to $\mathrm{F}_{6}(25.80 \mathrm{~g})$ and $\mathrm{F}_{3}(24.50 \mathrm{~g})$. It is noteworthy to indicate that the application of $\mathrm{F}_{5}$ produced greater dry matter mass of $24.83 \mathrm{~g}$ when compared to $\mathrm{F}_{3}(24.50)$; and a higher leaf area and dry matter mass when compare to $\mathrm{F}_{1}\left(19.20 \mathrm{dm}^{2}\right.$ and $\left.23.30 \mathrm{~g}\right)$ respectively.

Previous studies by Khaliq et al. (2006) reported that, the sink capacity of a plant is mainly dependent on its vigorous vegetative growth; as such in our study, the treatments that recorded a large leaf area plant ${ }^{-1}$, had more green areas available for the interception of active radiation during photosynthesis, for greater dry matter production (Azarpour et al., 2014). The regression analysis showed the impact of leaf area on dry matter produced by the fertilizers $\left(\mathrm{R}^{2}=0.8361\right)$ as shown in Figure 2.Dry matter production responded positively to an increase in leaf area plant ${ }^{-1}$. Our results are also in agreement with Raj \& Mallick (2017), in their studies the application of $80 \mathrm{~kg} \mathrm{~N} \mathrm{ha}^{-1}+$ mixed spray of $0.203 \% \mathrm{Ca}\left(\mathrm{NO}_{3}\right)_{2}+0.25 \% \mathrm{KNO}_{3}$ produced the maximum leaf area index values (1.748 and 1.592), dry matter accumulation (1404.3 and $1288.8 \mathrm{~g} \mathrm{~m}^{-2}$ ) and crop growth rate $\left(27.87\right.$ and $25.68 \mathrm{~g} \mathrm{~m}^{-2}$ day $\left.^{-1}\right)$.

\subsection{INFLUENCE OF TREATMENTS ON SOYBEAN YIELD COMPONENTS, YIELD, QUALITY AND WATER USE EFFICIENCY}

The data in Table 3 showed a significant $(p<0.05)$ impact of land configuration and fertilizer on soybean yield components. Interactions between the factors were not significant. Pod mass plant ${ }^{-1}$, grain mass plant ${ }^{-1}$ and 1000 seeds mass were significantly influenced by the different land configurations. The highest (12.32 g, 5.09 $\mathrm{g}$ and $85.56 \mathrm{~g}$ ) respectively, were produced by BBF. This resulted to its greatest grain yield of $1058.97 \mathrm{~kg} \mathrm{ha}^{-1}$ as well, but it was comparable to RF (1026.77 $\left.\mathrm{kg} \mathrm{ha}^{-1}\right)$ as shown in the Table 4 . The soybean yield were in accordance with the vegetative growth record by the land configurations. BBF significantly increased grain yield by $8.8 \%$, when compared to FB. Straw yield, biological yield and harvest index did not vary significantly among the land configurations, nevertheless the greatest values were observed in BBF, and was followed by RF. A similar results had been previously reported in 
Table 2: Influence of treatments on soybean growth

\begin{tabular}{|c|c|c|c|c|c|}
\hline Treatments & $\begin{array}{l}\text { Plant height } \\
\text { plant }^{-1}(\mathrm{~cm})\end{array}$ & $\begin{array}{l}\text { Number of leaves } \\
\text { plant }^{-1}\end{array}$ & $\begin{array}{l}\text { Number of } \\
\text { branches } \\
\text { plant }^{-1}\end{array}$ & $\begin{array}{l}\text { Leaf area } \\
\text { plant }^{-1}\left(\mathrm{dm}^{2}\right)\end{array}$ & $\begin{array}{l}\text { Total dry matter mass } \\
\text { plant }^{-1}(\mathrm{~g})\end{array}$ \\
\hline \multicolumn{6}{|c|}{ Land Configurations } \\
\hline FB & $46.83^{\mathrm{b}}$ & 16.68 & $3.82^{\mathrm{c}}$ & $17.98^{\mathrm{b}}$ & 23.20 \\
\hline $\mathrm{RF}$ & $49.60^{\mathrm{b}}$ & 19.52 & $4.05^{\mathrm{b}}$ & $18.90^{\mathrm{ab}}$ & 23.72 \\
\hline $\mathrm{BBF}$ & $55.98^{\mathrm{a}}$ & 19.53 & $4.95^{\mathrm{a}}$ & $21.47^{\mathrm{a}}$ & 24.20 \\
\hline CD@ 5 \% & 3.51 & NS & 0.19 & 2.63 & NS \\
\hline \multicolumn{6}{|l|}{ Fertilizers } \\
\hline $\mathrm{F}_{1}$ & $50.90^{\mathrm{ab}}$ & 18.43 & $4.10^{\mathrm{cd}}$ & $19.20^{\mathrm{bc}}$ & $23.30^{\mathrm{ab}}$ \\
\hline $\mathrm{F}_{2}$ & $46.57^{\mathrm{b}}$ & 16.97 & $3.70^{\mathrm{e}}$ & $17.40^{c}$ & $22.23^{\mathrm{b}}$ \\
\hline $\mathrm{F}_{3}$ & $53.67^{\mathrm{a}}$ & 19.20 & $4.47^{\mathrm{b}}$ & $20.47^{\mathrm{ab}}$ & $24.50^{\mathrm{ab}}$ \\
\hline $\mathrm{F}_{4}$ & $49.44^{\mathrm{ab}}$ & 17.60 & $3.93^{\mathrm{de}}$ & $18.03^{\mathrm{c}}$ & $21.57^{\mathrm{b}}$ \\
\hline $\mathrm{F}_{5}$ & $51.13^{\mathrm{ab}}$ & 19.10 & $4.27^{\mathrm{bc}}$ & $19.50^{\mathrm{bc}}$ & $24.83^{\mathrm{ab}}$ \\
\hline $\mathrm{F}_{6}$ & $53.12^{\mathrm{a}}$ & 20.17 & $5.17^{\mathrm{a}}$ & $22.10^{\mathrm{a}}$ & $25.80^{\mathrm{a}}$ \\
\hline CD@ 5 \% & 5.42 & NS & 0.32 & 2.22 & 2.72 \\
\hline
\end{tabular}

Note: mean values with different superscript letter within each column denotes significance $(\mathrm{p}<0.05)$ between different groups. CD $=$ critical difference between means; NS = non-significant $(\mathrm{n}=15)$

other crops. In a study, Pramanik et al. (2009) reported a significant $16.8 \%$ and $15.9 \%$ rise in chickpea grain yield under raised bed planting over flatbed planting, in two seasons. According to Selvarajua et al. (1999) also, planting on BBF increased sorghum and pearl millet yields by $34 \%$ and $33 \%$ respectively, compared to FB. This they ascribed to the optimum water storage and safe disposal of excess rain water by BBF. Among all the in situ soil moisture conservation techniques, rain water use efficiency was the highest (3.76 $\left.\mathrm{kg} \mathrm{ha}^{-1}-\mathrm{mm}\right)$ in BBF as well (Table 4). It is evident from the Table 4 that, an increase in water use efficiency corresponded to a greater soybean yield. When water utilization increased, nutrient uptake was enhanced by the mass flow process. Previous work of Lomte et al. (2006) also showed that, opening of furrows in every row recorded the highest water use efficiency of $3.15 \mathrm{~kg} \mathrm{ha}^{-1}$-mm than flat bed.

Among the fertilizers also, the application of $\mathrm{F}_{6}$ recorded the greatest yield components; pod number plant ${ }^{-1}$ (30.65), pod mass plant ${ }^{-1}(13.40 \mathrm{~g})$, grain mass plant $^{-1}(5.36 \mathrm{~g})$ and 1000 seeds mass $(95.56 \mathrm{~g})$. However, grain yield $\mathrm{ha}^{-1}$ was on a par between $\mathrm{F}_{6}$ $(1160.33 \mathrm{~kg})$ and $F_{5}(1086.50 \mathrm{~kg})$. A similar trend was noticed for straw yield and biological yield between the two treatments, and were followed by $\mathrm{F}_{3}$. In addition, an increase in NPK rate from F1 to F3, also significantly increased grain yield by $2.3 \%$ (Table 4 ). Additionally, the yield increment realized for $\mathrm{F}_{6}$ and
$\mathrm{F}_{5}$ were $15.6 \%$ and $9.9 \%$ respectively, higher compared to the recommended fertilizer rate $\left(\mathrm{F}_{1}\right)$. The higher yield of $\mathrm{F}_{6}$ was mainly due to its greater grain mass plant ${ }^{-1}$ and 1000 seed mass. The $\mathrm{KNO}_{3}$ sprayed during the seed filling stages (60 DAS) might had increased the availability of $\mathrm{N}$ and $\mathrm{K}$ to the plants. $\mathrm{N}$ is central in organic compounds formation in plants (Intanon, 2013). Besides the beneficial functions of nitrate nitrogen, the prevalence of $\mathrm{K}^{+}$in $\mathrm{KNO}_{3}$, may had also improved grain filling and phytomass production, and the translocation of assimilates to reproductive apparatus (Ravikiran et al., 2012; Waraich et al., 2011). The relationship between leaf area plant $^{-1}$ and grain mass plant ${ }^{-1}\left(\mathrm{R}^{2}=0.8276\right)$ showed that, the high vegetative growth produced affected grain yield positively (Figure 2).

Our result are in line with those of other previous experiments as well. Soil application of $80 \mathrm{~kg} \mathrm{~N} \mathrm{ha}^{-1}$ + foliar spray of $0.25 \% \mathrm{KNO}_{3}+0.203 \% \mathrm{Ca}\left(\mathrm{NO}_{3}\right)_{2}$, led to an increased soybean yield of $1.68 \mathrm{t} \mathrm{ha}^{-1}$, about $10.7 \%$ increase over the $1.5 \mathrm{t} \mathrm{ha}^{-1}$ produced by $80 \mathrm{~kg}$ $\mathrm{N} \mathrm{ha}^{-1}+$ water spray (Raj \& Mallick, 2017).

Again, Vekaria et al. (2013) reported that foliar application of $0.4 \% \mathrm{KNO}_{3} \mathrm{ha}^{-1}$ significantly increased soybean yield by $18.4 \%$ when compared to water spray only. Intanon (2013) did mentioned that, the micronutrient $(\mathrm{Fe}, \mathrm{Zn}$ and $\mathrm{Cu})$ are important for carbohydrate formation. The presence of this element in $F_{5}$ could partly account for its high yield output. 
Table 3: Influence of treatments on soybean yield components

\begin{tabular}{|c|c|c|c|c|}
\hline Treatments & Pods plant ${ }^{-1}$ & Pod mass plant ${ }^{-1}(\mathrm{~g})$ & Grain mass plant ${ }^{-1}(\mathrm{~g})$ & 1000 seeds mass (g) \\
\hline \multicolumn{5}{|c|}{ Land Configurations } \\
\hline FB & 27.71 & $11.45^{\mathrm{b}}$ & $3.76^{\mathrm{b}}$ & $81.77^{\mathrm{b}}$ \\
\hline $\mathrm{RF}$ & 28.19 & $11.87^{\mathrm{ab}}$ & $4.55^{\mathrm{a}}$ & $82.72^{\mathrm{ab}}$ \\
\hline $\mathrm{BBF}$ & 29.68 & $12.32^{\mathrm{a}}$ & $5.09^{\mathrm{a}}$ & $85.56^{\mathrm{a}}$ \\
\hline CD @ 5\% & NS & 0.48 & 0.58 & 3.24 \\
\hline \multicolumn{5}{|l|}{ Fertilizers } \\
\hline $\mathrm{F}_{1}$ & 28.28 & $11.41^{\mathrm{bc}}$ & $4.23^{\mathrm{bcd}}$ & $79.84^{\mathrm{b}}$ \\
\hline $\mathrm{F}_{2}$ & 26.85 & $10.26^{c}$ & $3.75^{\mathrm{d}}$ & $76.52^{\mathrm{b}}$ \\
\hline $\mathrm{F}_{3}$ & 28.51 & $12.44^{\mathrm{ab}}$ & $4.50^{\mathrm{bc}}$ & $82.86^{\mathrm{b}}$ \\
\hline $\mathrm{F}_{4}$ & 27.65 & $10.95^{c}$ & $4.01^{\mathrm{cd}}$ & $77.35^{\mathrm{b}}$ \\
\hline $\mathrm{F}_{5}$ & 29.20 & $12.83^{\mathrm{ab}}$ & $4.92^{\mathrm{b}}$ & $84.95^{\mathrm{b}}$ \\
\hline $\mathrm{F}_{6}$ & 30.65 & $13.40^{\mathrm{a}}$ & $5.36^{\mathrm{a}}$ & $96.56^{\mathrm{a}}$ \\
\hline CD @ 5 \% & NS & 1.75 & 0.74 & 9.04 \\
\hline
\end{tabular}

Note: mean values with different superscript letter within each column denotes significance $(p<0.05)$ between different groups. CD = critical difference between means; NS = non-significant $(\mathrm{n}=15)$.

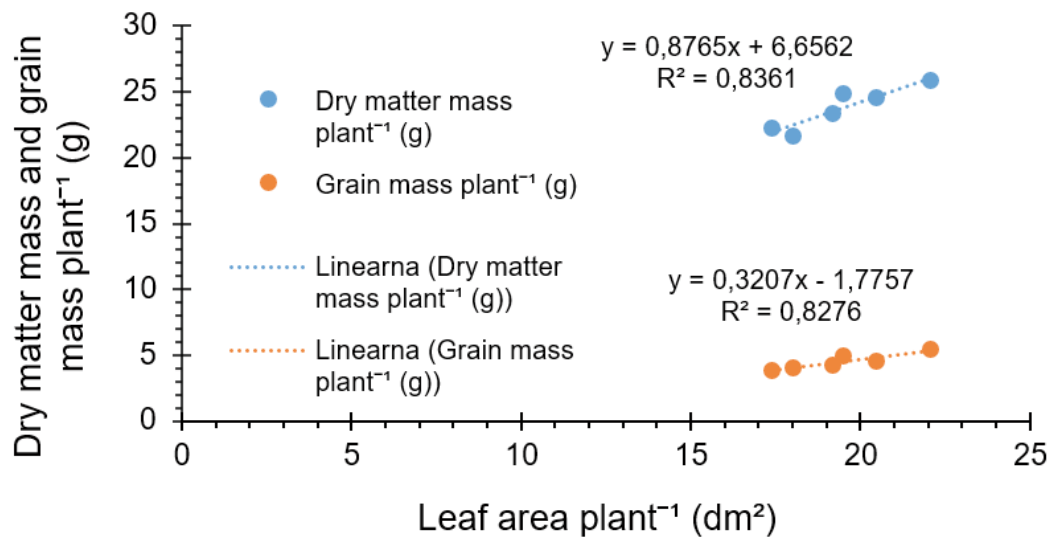

Figure 2: Regression analysis of leaf area plant $t^{-1}\left(\mathrm{dm}^{2}\right)$ to total dry matter plant ${ }^{-1}$ and grain mass plant ${ }^{-1}(\mathrm{~g})$

The impact of boron $\left(1 \mathrm{~kg} \mathrm{ha}^{-1}\right)$ and molybdenum $\left(0.5 \mathrm{~kg} \mathrm{ha}^{-1}\right)$ on soybean yield had been demonstrated (Adkine et al., 2011); while the combination of NPK with $400 \mathrm{~g} \mathrm{Fe} \mathrm{ha}^{-1}$ and $20 \mathrm{~g} \mathrm{Mo} \mathrm{ha}^{-1}$ had also been reported by (Zahoor et al., 2013). In our work, land configuration had no significant effect on seed protein and oil content; likewise was the fertilizers on seed oil content, but numerically, the highest oil content of $19.65 \%$ was obtained in $\mathrm{F}_{5}$ and the lowest in $\mathrm{F}_{2}$ (Figure $3)$. Seed protein content was significantly $(p<0.05)$ influenced by the fertilizers, with the highest $(39.64 \%$, $39.38 \%, 39.33 \%$ and $39.18 \%$ ) realized in $\mathrm{F}_{6}, \mathrm{~F}_{5}, \mathrm{~F}_{3}$, and $\mathrm{F}_{4}$, respectively. The seed qualities observed in our study concur with those of (Kiran et al., 2008).

\subsection{SOIL FERTILITY AFTER THE TRAIL}

The different in situ soil moisture conservation techniques had no significant influence on soil fertility after the trial, though the best recordings were noticed in BBF (Table 5). The more soil water conserved in BBF, probably increased the crop residues added to the soil due to high vegetative growth (Selvarajua et al., 1999; Lal, 1995). The residual soil nitrogen $(11.14 \%)$, phosphorus $(0.73 \%)$ and potassium $(1.85 \%)$ contents were greatest in $\mathrm{F}_{3}$ plots, probably due to the high NPK levels of this fertilizer formula. Phosphorous and potassium contents in particular, were significantly $(p<0.05)$ improved by $F_{3}$, when 
Table 4: Influence of treatments on soybean yield, harvest index and rain water use efficiency.

\begin{tabular}{|c|c|c|c|c|c|}
\hline Treatments & $\begin{array}{l}\text { Grain yield } \\
\left(\mathrm{kg} \mathrm{ha}^{-1}\right)\end{array}$ & $\begin{array}{l}\text { Straw yield } \\
\left(\mathrm{kg} \mathrm{ha}^{-1}\right)\end{array}$ & $\begin{array}{l}\text { Biological yield } \\
\left(\mathrm{kg} \mathrm{ha}^{-1}\right)\end{array}$ & $\begin{array}{l}\text { Harvest index } \\
(\mathrm{HI})\end{array}$ & $\begin{array}{l}\text { RWUE } \\
\left(\mathrm{kg} \mathrm{ha}^{-1} \mathrm{~mm}^{-1}\right)\end{array}$ \\
\hline \multicolumn{6}{|c|}{ Land Configurations } \\
\hline FB & $966.10^{\mathrm{b}}$ & 1913.00 & 2879.10 & 0.34 & $3.43^{\mathrm{b}}$ \\
\hline $\mathrm{RF}$ & $1026.77^{\mathrm{ab}}$ & 1985.83 & 3012.60 & 0.34 & $3.64^{\mathrm{ab}}$ \\
\hline $\mathrm{BBF}$ & $1058.97^{\mathrm{a}}$ & 2085.67 & 3144.63 & 0.34 & $3.76^{\mathrm{a}}$ \\
\hline CD@ $5 \%$ & 63.13 & NS & NS & NS & 0.22 \\
\hline \multicolumn{6}{|l|}{ Fertilizers } \\
\hline $\mathrm{F}_{1}$ & $979.03^{c}$ & $1992.00^{\mathrm{abc}}$ & $2971.03^{\mathrm{bc}}$ & 0.33 & $3.48^{c}$ \\
\hline $\mathrm{F}_{2}$ & $916.37^{c}$ & $1820.33^{c}$ & $2736.70^{\mathrm{d}}$ & 0.34 & $3.25^{\mathrm{c}}$ \\
\hline $\mathrm{F}_{3}$ & $1001.70^{\mathrm{b}}$ & $2019.33^{\mathrm{ab}}$ & $3021.03^{\mathrm{bc}}$ & 0.33 & $3.56^{\mathrm{bc}}$ \\
\hline $\mathrm{F}_{4}$ & $959.73^{c}$ & $1905.00^{\mathrm{bc}}$ & $2864.73^{\mathrm{cd}}$ & 0.34 & $3.41^{\mathrm{c}}$ \\
\hline $\mathrm{F}_{5}$ & $1086.50^{\mathrm{ab}}$ & $2062.33^{\mathrm{ab}}$ & $3148.83^{\mathrm{ab}}$ & 0.34 & $3.86^{\mathrm{ab}}$ \\
\hline $\mathrm{F}_{6}$ & $1160.33^{\mathrm{a}}$ & $2170.00^{\mathrm{a}}$ & $3330.33^{\mathrm{a}}$ & 0.35 & $4.12^{\mathrm{a}}$ \\
\hline CD@ 5 \% & 99.91 & 197.79 & 216.12 & NS & 0.35 \\
\hline
\end{tabular}

Note: mean values with different superscript letter within each column denotes significance $(p<0.05)$ between different groups. CD $=$ critical difference between means; $\mathrm{NS}=$ non-significant.

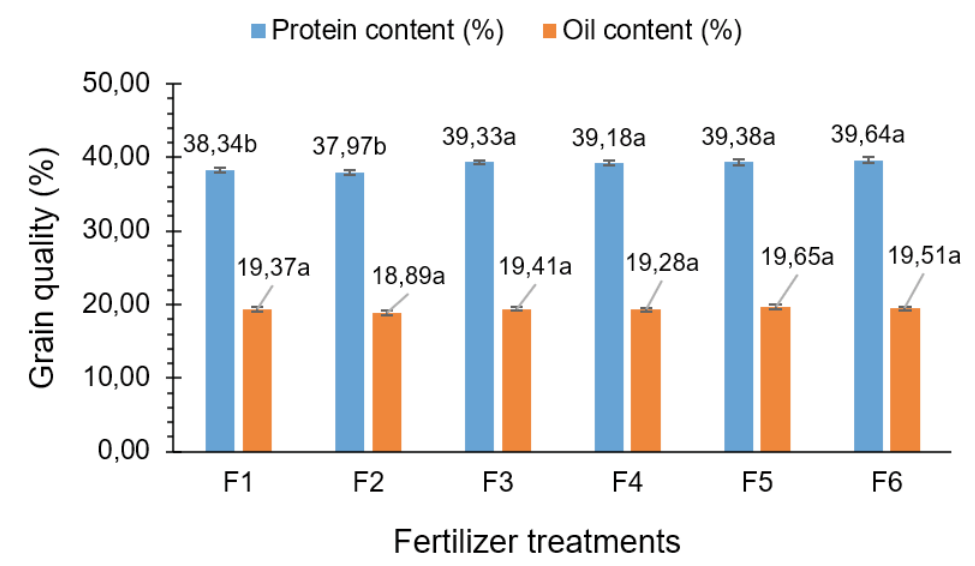

Figure 3: Influence of fertilizers on grain quality $(n=3)$

compared to the other fertilizers. Generally, soil nitrogen and phosphorus content improve in all the plots, when compared to the levels before the trial. Our findings could be due to the Rhizobium culture (Bradyrhizobium japonicum) and phosphate solubilizing bacteria (PSB) treatment given to the seeds, as root nodules formations were generally observed on most roots. Also, the soil micronutrients; $\mathrm{Fe}, \mathrm{Zn}, \mathrm{Cu}$, $\mathrm{Mn}$ and $\mathrm{B}$ contents were found the highest in $\mathrm{F}_{5}$ with $8.75,2.10,0.60,3.31$ and $1.40 \mathrm{mg} \mathrm{kg}^{-1}$, respectively. This could be due to the micronutrient spray given under this treatment. The lowest performance were observed in the $\mathrm{F}_{2}$ plots.

\section{CONCLUSION}

Our result supports our hypothesis that (i) proper land configuration can promote soybean yield than flatbed; (ii) proper fertilization technique (foliar spray) can improve soybean yield and soil fertility. Our work has shown that BBF and RF can conserve more soil moisture for greater soybean growth and yield in vertisol soil. The application of $\mathrm{F}_{6}$ also produced the highest soybean growth and yield. Therefore, for general soil improvement, the application of $\mathrm{F}_{5}$ is recommended as it improved both the macro and micro soil nutrients elements, however for maximum yield, farmers in the 
Table 5: Soil fertility after the trail

\begin{tabular}{|c|c|c|c|c|c|c|c|c|}
\hline \multirow[t]{2}{*}{ Treatments } & $\mathrm{N}$ & $\mathrm{P}$ & $\mathrm{K}$ & $\mathrm{Fe}$ & $\mathrm{Zn}$ & $\mathrm{Cu}$ & $\mathrm{Mn}$ & $\mathrm{B}$ \\
\hline & \multicolumn{5}{|c|}{$\%$} & \multicolumn{3}{|c|}{$\mathrm{mg} / \mathrm{kg}$} \\
\hline \multicolumn{2}{|l|}{ Land Configurations } & \multicolumn{7}{|l|}{$\mathrm{mg} / \mathrm{kg}$} \\
\hline FB & 0.99 & 0.67 & 1.71 & 6.11 & 1.50 & 0.40 & 2.65 & 0.62 \\
\hline $\mathrm{RF}$ & 0.98 & 0.66 & 1.71 & 6.23 & 1.53 & 0.39 & 2.66 & 0.58 \\
\hline $\mathrm{BBF}$ & 0.99 & 0.69 & 1.73 & 6.43 & 1.57 & 0.42 & 2.68 & 0.62 \\
\hline CD@ 5 \% & NS & NS & NS & NS & NS & NS & NS & NS \\
\hline \multicolumn{9}{|l|}{ Fertilizers } \\
\hline $\mathrm{F}_{1}$ & $1.06^{\mathrm{b}}$ & $0.71^{\mathrm{ab}}$ & $1.79^{\mathrm{b}}$ & $5.68^{c}$ & $1.50^{\mathrm{b}}$ & $0.34^{\mathrm{c}}$ & $2.50^{\mathrm{bc}}$ & $0.40^{\mathrm{d}}$ \\
\hline $\mathrm{F}_{2}$ & $0.84^{c}$ & $0.60^{\mathrm{d}}$ & $1.60^{\mathrm{d}}$ & $5.59^{c}$ & $1.44^{\mathrm{b}}$ & $0.35^{c}$ & $2.39^{c}$ & $0.41^{\mathrm{d}}$ \\
\hline $\mathrm{F}_{3}$ & $1.14^{\mathrm{a}}$ & $0.73^{a}$ & $1.85^{\mathrm{a}}$ & $5.77^{\mathrm{c}}$ & $1.36^{\mathrm{b}}$ & $0.37^{\mathrm{b}}$ & $2.36^{c}$ & $0.43^{\mathrm{cd}}$ \\
\hline $\mathrm{F}_{4}$ & $0.89^{c}$ & $0.67^{c}$ & $1.71^{\mathrm{c}}$ & $6.16^{\mathrm{b}}$ & $1.43^{\mathrm{b}}$ & $0.39^{\mathrm{b}}$ & $2.88^{\mathrm{b}}$ & $0.48^{b c}$ \\
\hline $\mathrm{F}_{5}$ & $0.85^{\mathrm{c}}$ & $0.64^{\mathrm{cd}}$ & $1.61^{\mathrm{d}}$ & $8.75^{\mathrm{a}}$ & $2.10^{\mathrm{a}}$ & $0.60^{\mathrm{a}}$ & $3.31^{\mathrm{a}}$ & $1.40^{\mathrm{a}}$ \\
\hline $\mathrm{F}_{6}$ & $1.13^{\mathrm{ab}}$ & $0.68^{\mathrm{bc}}$ & $1.74^{\mathrm{bc}}$ & $5.58^{c}$ & $1.39^{\mathrm{b}}$ & $0.36^{\mathrm{b}}$ & $2.46^{c}$ & $0.54^{\mathrm{b}}$ \\
\hline CD@ 5 \% & 0.07 & 0.04 & 0.05 & 0.29 & 0.22 & 0.03 & 0.38 & 0.06 \\
\hline
\end{tabular}

Note: mean values with different superscript letter within each column denotes significance $(p<0.05)$ between different groups. CD $=$ critical difference between means; NS = non-significant $(n=3)$.

Marathwada region of India are advise to adopt BBF + $\mathrm{F}_{6}$ for soybean production.

\section{ACKNOWLEDGEMENT}

The research was funded by the All India Coordinated Research Project on Dryland Agriculture, Vasantrao Naik Marathwada Agriculture University, Maharashtra, India.

\section{REFERENCES}

A.O.A.C. (1975). Official and tentative methods of the analysis, tenth edition. Association of Official Analytical Chemist, Washington D.C.

Adkine, P. M., Mankar, D. D., Khandait, V. M., Bhandare, V. L., \& Nawlakhe, S.M. (2011). Effect of boron, molybdenum and potassium nitrate on growth, yield and economics of soybean. Journal of Soils and Crops, 21, 116-123.

Azarpour, E., Moraditochaee, M., \& Bozorgi, H. R. (2014). Effect of nitrogen fertilizer management on growth analysis of rice cultivars. International Journal of Biosciences, 4, 3547. https://doi.org/10.12692/ijb/4.5.35-47

Bharambe, P. R., Oza, S. R., \& Shelke, D. K. (1999). Effect of irrigation on crop productivity and soil plant water relation in soybean Rabi sorghum cropping system. Journal of the Indian Society of Soil Science, 47, 689-694.

Chaturvedi, S., Chandel, A. S., \& Singh, A. P. (2012). Nutrient management for enhanced yield and quality of soybean
(Glycine max. L.) residual soil fertility. Legume Research, 35, 175-184.

Gowthami, P., \& Rama Rao, C. (2014). Effect of foliar application of potassium, boron, and zinc on growth analysis and seed yield in soybean. International Journal of Food, Agriculture \& Veterinary Sciences, 4, 73-80.

Intanon, P. (2013). The influence of different types of fertilizers on productivity and quality of maize in the area of Kwaew Noi Bamrungdan Dam, Phitsanulok Province, Thailand. International Journal of Environmental and Rural Development, 4, 15-20.

Keteku, A. K., Narkhede, W. N., \& Khazi, G. S. (2016). Effect of fertility levels on growth, yield and soil fertility status of maize (Zea mays L.) in vertisol of Maharashtra. Journal of Applied and Natural Sciences, 8, 1779-1785. https://doi. org/10.31018/jans.v8i4.1040

Keteku, A. K., Intanon, P., Terapongtanakorn, S., \& Intanon, R. (2018). Evaluation of fertilizer management on yield and yield components and production economics of 'Pacific 999 Super' maize cultivar. World Research Journal of Agricultural Sciences, 5, 147-156.

Khaliq, A., Abbasi, M. K., \& Hussain, T. (2006). Effects of integrated use of organic and inorganic nutrient sources with effective microorganisms (EM) on seed cotton yield in Pakistan. Bioresource Technology, 97, 967-972. https://doi. org/10.1016/j.biortech.2005.05.002

Kiran, J. A., Lingaraju, B. S., \& Ananda, N. (2008). Influence of in situ moisture content, yield and nutrient uptake of Rabi sorghum under rainfed condition. Crop Research, 35, 8-12.

Kumar, A., Sharma. K. D., \& Yadav, A. (2010). Enhancing yield and water productivity of wheat (Triticum aestivum) through furrow irrigated raised bed system in the Indo- 
Gangetic Plains of India. Indian Journal of Agricultural Sciences, 80, 198-202.

Kurukulasuriya, P., \& Rosenthal, S. (2003). Climate change and agriculture. A review of impacts and adaptations. The World Bank Climate Change Series, vol. 9. World Bank Environment Department, Washington. District of Colombia, $96 \mathrm{pp}$.

Lal, R. (1995). Tillage systems in the tropics, management options and sustainability implications. FAO Soils bulletin No. 71, Rome, Italy.

Lomte, D. M., Umate, M. G., Kausaleand, S. P., \& Kote, G. M. (2006). Effect of different land configuration on yield of soybean (Glycine max (L) Merrill.) genotypes under rainfed conditions. Legume Research, 29, 295-297.

Lu, R. K. (1999). Analytical methods of soil and agricultural chemistry. China Agricultural Science and Technology Press, Beijing.

Nsoanya, L. N., \& Nweke, I. A. (2013). Effect of integrated use of spent grain and NPK (20: 10: 10) fertilizer on soil chemical properties and maize (Zea Mays L) growth. International Journal of Agricultural, Forestry \& Plantation, 2, 14-19.

Patil, S. N., Morey, D. K., Deshmukh, S. R., \& Balkar, S. Y. (1992). Performance of land configurations for better insitu moisture conservation and crop yield. PDKV Research Journal, 16, 74 .

Pawar, U. P., Surnaik, N. T., \& Sondge, U. P. (1978). Effect of nitrogen and phosphate on yield and quality of soybean varieties. Journal of Maharashtra Agricultural University, 7, 90-92.

Pramanik, S. C., Singh, N. B., \& Singh, K. K. (2009). Yield, economics and water use efficiency of chickpea (Cicer arietinum) under various irrigation regimes on raised bed planting system. Indian Journal of Agronomy, 54, 315-318.

Raj, A., \& Mallick, R. B. (2017). Effect of nitrogen and foliar spray of potassium nitrate and calcium nitrate on growth and productivity of yellow sarson (Brassica campestris 'Yellow Sarson') crop under irrigated condition. Journal of Applied and Natural Sciences, 9, 888-892. https://doi. org/10.31018/jans.v9i2.1293

Raut, V. M., \& Taware, S. P. (1997). Comparison of different sowing methods in soybean. Journal of Maharashtra Agricultural University, 25, 218-219.

Ravikiran, S., Halepyati, A. S., Pujari, B. T., Koppalakar, B. G., \& Narayanarao, K. (2012). Effect of macro and soluble micronutrients on yield, uptake of nutrients, quality and economics of Bt cotton (Gossypium hirsutum L.) under irrigation. Karnataka Journal of Agricultural Sciences, 25, 418-422.

Salem, H. M., \& El-Gizawy, N. K. B. (2012). Importance of micronutrients and its application methods for improving maize (Zea mays L.) yield grown in clayey soil. AmericanEurasian Journal of Agricultural \& Environmental Sciences, 12, 954-959.

Selvarajua, P., Subbiana, A., Balasubramaniana, R., \& Lal. (1999). Land configuration and soil nutrient management options for sustainable crop production on alfisols and vertisols of southern peninsular India. Soil Tillage Research, 52, 203-216. https://doi.org/10.1016/ S0167-1987(99)00083-5

Shinde, V. S., Deshmukh, L. S., Shinde, S. A., \& Zade, K. K. (2009). Influence of rainwater management through different agro-techniques on yield, yield attributing characters and economics of cotton. Journal of Cotton Research and Development, 23, 51-55.

Singh, A.K., \& Kumar, P. (2009). Nutrient management in rainfed dryland agro ecosystem in the impending climate change scenario. Agricultural Situ India Journal, 66, 265270.

Singh, L., Mirza, K. A. B., Akhter, S., Qayoom, S., Lone, B. A., Singh, P., \& Singh, P. (2014). Efficient techniques to increase water use efficiency under rainfed eco-systems. Journal of AgriSearch, 1, 193-200.

Singh, J., Kumari, A., Jain, R., \& Pachlaniya, N. (2018). Effect of different land configuration on the yield of soybean (Glycine max L.). International Journal of Agricultural Engineering, 11, 135-137. https://doi.org/10.15740/HAS/ IJAE/11.1/135-137

Talukdar, A., \& Shivakumar, M. (2016). Genetic improvement of food-grade soybean in India: Current status and future prospects. Indian Journal of Genetics and Plant, 76, 626630. https://doi.org/10.5958/0975-6906.2016.00077.8

Vekaria, G. B., AU - Talpada, M. M., AU - Sutaria, G. S., \& AU - Akbari, K. N. (2013). Effect of foliar nutrition of potassium nitrate on the growth and yield of greengram (Vigna rabiata L.). Legume Research, 36, 162-164.

Waraich, E. A., Ahmad, R., Raja, G. M., Ehsanullah Ahmad, A., \& Nasir, M. (2011). Response of foliar application of $\mathrm{KNO}_{3}$ on yield, yield components and lint quality of cotton (Gossypium hirsutum L.). African Journal of Agricultural Research, 6, 5457-5463.

Zahoor, F., Ahmed, M., Malik, M. A., Mubeen, K., Siddiqui, M. H, Rasheed, M., Ansar, R. \& Mehmood, K. (2013). Soybean (Glycine max L.) response to micronutrients. Turkish Journal of Field Crops, 18, 134-138. 